\title{
METODE PENANAMAN KEAGAMAAN PADA ANAK USIA DINI
}

\author{
Bahrul Ulum \\ Program Studi Pendidikan Bahasa Arab STAI As-Sunnah Deli Serdang \\ Jl. Medan-Tg. Morawa, Km. 13, Gang Darmo, Desa Bangun Sari, Kecamatan Tanjung Morawa, \\ Kabupaten Deli Serdang, SUMUT
}

\begin{abstract}
Abstrak:Pendidikan anak usia dini merupakan pendidikan yang dilaksanakan pada usia 0-6 tahun, yang mana pada pendidikan formalnya dilaksanakan pada usia 4-6 tahun. Hal ini sesuai dengan yangterdapat dalam kurikulum berbasis kompetensi yang menjelaskan bahwa anak usia dini 4-6 tahun merupakan bagian dari anak usia dini yang berada pada rentang usia lahir sampai 6 tahun. Pada usia ini secara terminology disebut sebagai anak usia prasekolah. Ilmu Agama sangat penting ditanamkan pada usia ini. Peran orang tua dalam menanamkan rasa kesadaran keberagamaan bisa dilakukan semenjak anak masih dalam kandungan. Kemudian dilanjutkan pada lingkungan keluarga. Orang tua bisa memberikan contoh perilaku yang baik terhadap tetangga, terhadap lingkungan sekitar rumah, dan binatang. Orang tua juga harus membiasakan anak untuk membaca Al-Qur'an, shalat secara berjamaah, mendengarkan ceramah dan lainlain. Sedangkan melalui tutur kata, orang tua dapat membiasakan anak untuk berbicara sopan, jujur, dan lemah lembut kepada orang tua, guru, teman, dan orang sekitarnya. Masalah pokok yang ditulis dalam tulisan ini adalah, Bagaimana bentuk penanaman keagamaan pada anak usia dini dan Faktor-faktor apa saja yang mendukung dan menghambat dalam penanaman keagamaan pada anak usia dini.
\end{abstract}

Kata Kunci: Metode, Penanaman Keagamaan, Anak Usia Dini

\section{Pendahuluan}

Pertumbuhan anak di usia dini amat penting dan menentukan. Apa yang terbentukdi usia itu akan mempengaruhi tingkat kecerdasan dari watak atau kepribadian anak selanjutnya. Maka oleh karena itu, pendidikan di usia dini amat penting dan strategis.

Di sisi lain, hingga saat ini masih banyak kalangan masyarakat yang belum menyadari hal tersebut, sehingga kadang tanpa disadari anak diperlakukan dengan keliru yang pada akhirnya dapat merusak atau menghambat pertumbuhan anakmaka oleh karenanya, diperlukan upaya-upaya untuk memperbaikinya secara sungguh sungguh dengan menggunakan metode yang tepat.

Apabila anak diarahkan sesuai dengan kapasitas, potensi dan perkembangan serta tahapan-tahapan yang akan dilaluinya, maka anak menjadi penyejuk sanubari dan menyenangkan bila dipandang mata.Ilmu pendidikan 
telah berkembang pesat dan terspesialisasi, Salah satu diantaranya pendidikan anak usia dini, yaitu pendidikan untuk anak usia 0-6 tahun yang diselenggarakan sebelum masuk pendidikan dasar.Pada usia tersebut anak dipandang mempunyai karakteristik yang berbeda dengan anak usia diatasnya sehingga pendidikan perlu dikhususkan.Pada rentang usia 0-6 itu anak anak mendapat pendidikan baik dari keluarganya, kelompok bermain ataupun pendidikan sekolah yang khusus.

\section{Pembahasan}

\section{A. Pengertian Pendidikan Anak Usia Dini}

Untuk mengetahui lebih jauh tentang pengertian pendidikan anakusia dini, maka penulis akan memaparkan terlebih dahulu pengertianpendidikan. Dalam Kamus Besar Bahasa Indonesia pendidikan diartikan sebagai proses perubahan sikap dan tata laku seseorang atau kelompok orang dalam usaha mendewasakan manusia melalui upaya pengajaran dan pelatihan. ${ }^{1}$

Secara umum pendidikan adalah upaya membentuk orientasi indivdu-individu menurut norma-norma tertentu dan membantu mereka dalam membentuk pandangan yang benar dalam kehidupan. Dan pendidikan itu diiringi dengan proses pembelajaran yang bisa mengkilapkan kemampuan mereka dan mengembangkat bakat dan potensi mereka di berbagai bidang. ${ }^{2}$

Sedangkan pendidikan Islam berarti mengembangkan potensi dan kemampuan individu yang beragam untuk mencapai kemampuan akal dan jiwa. Disamping itu juga mengembangkan potensi masyarakat untuk mewujudkan perkembangan yang lebih baik dan kemajuan sosial yang lebih lengkap sesuai prinsip-prinsip dan nilai-nilai Islam. ${ }^{3}$

Dalam Undang-Undang Republik Indonesia No. 20 Tahun 2003tentang Sistem Pendidikan Nasional Bab I dijelaskan bahwa

${ }^{1}$ Kamus Besar Bahasa Indonesia, Pusat bahasa, Departemen Pendidikan Nasional (Jakarta: PT Gramedia, 2008), hal.326.

${ }^{2}$ Ahmad, Farid. Pendidikan Berbasis Metode Ahlu Sunnah Wal Jama'ah. (Surabaya: Pustaka Elba, 2011), hal.32.

${ }^{3}$ Ibid,. 
yangdimaksud dengan pendidikan adalah usaha sadar dan terencana untukmewujudkan suasana belajar dan proses pembelajaran agar peserta didiksecara aktif mengembangkan potensi dirinya untuk memiliki kekuatanspiritual keagamaan, pengendalian diri, kepribadian, kecerdasan, akhlakmulia, serta keterampilan yang diperlukan dirinya, masyarakat, bangsa dannegara. ${ }^{4}$

Kalau diamati, makna umum bagi kalimat pendidikan, hal itumencakup segala macam aktivitas yang berpengaruh pada kekuatanseseorang, kesiapan, dan pengembangannya. Dan sumber segala macamaktivitas tersebut ada berbagai macam faktor. Pendidikan mencakup setiapperubahan pada kecenderungan, watak, dan akhlak kita yang secara tidaklangsung dilengkapi oleh faktor-faktor lain, seperti norma-norma syari'at,atau norma-norma sipil, system pemerintahan, polapola kehidupan,tradisi-tradisi masyarakat, dan berbagai macam lingkungan.

Sedangkan untuk mengetahui pengertian pendidikan anak usia dini,maka ditemukan berbagai macam pendapat dari para tokoh yang simpangsiur. Yang dimaksud dengan anak usia dini sama dengan anak prasekolahyaitu mereka yang berusia 3-6 tahun. Mereka biasanya mengikutiprogram prasekolah dan kinderganten. Sedangkan di Indonesia umumnyamereka mengikuti program tempat penitipan anak (3-5 tahun) dankelompok bermain (3 tahun), sedangkan pada usia 4-6 tahun biasanyamereka mengikuti program taman kanak-kanak. ${ }^{5}$

Banyak orang yang masing-masing mempunyai pengertian yangtidak sama mengenai pendidikan anak usia dini atau pendidikanprasekolah, sehingga akan mengaburkan arah pembicaraannya. Meskipunterdapat perbedaan konsep anak usia dini di Negara maju dan Indonesia,namun The National Association For The Education Of Yaoung Children(NAEYC), menggunakan batasan sebagai berikut:

\footnotetext{
${ }^{4}$ Undang-Undang Republik Indonesia No. 20 Tahun 2003 tentang Sistem Pendidikan Nasional. (Bandung: Citra Umbara, 2003), hal. 3.

5 Soemiarti Patmonodewo. Pendidikana Anak Prasekolah. (Jakarta: PT. Rineka Cipta, 2008), hal. 19.
} 
a. Yang dimaksud dengan "Early Childhood" (anak masa awal)adalah anak yang sejak lahir sampai dengan usia delapan tahun. Haltersebut merupakan pengertian yang baku yang dipergunakan olehNAEYC. Batasan ini seringkali dipergunakan untuk merujuk anakyang belum mencapai usia sekolah dan masyarakat menggunakannya bagi berbagai tipe prasekolah (preschool)

b. Early Childhood setting (tatanan anak masa awal) menunjukkanpelayanan untuk anak sejak lahir sampai dengan delapan tahun disuatupusat penyelenggaraan, rumah, atau instusi, seperti kindergarten, sekolah dasar dan program rekreasi yang menggunakan sebagianwaktu atau penuh waktu.

c. Early Childhood Education (pendidikan awal masa anak) terdiridari pelayanan yang diberikan dalam tatanan awal masa anak.Biasanya oleh para pendidik anak usia dini (young children) digunakanistilah Early Childhood (anak masa awal) dan Early ChildhoodEducation (pendidikan awal masa anak) dianggap sama. ${ }^{6}$

Sesuai dengan penjelasan di atas dapat diketahui bahwa diIndonesia pendidikan anak usia dini merupakan pendidikan yangdilaksanakan pada usia 0-6 tahun, yang mana pada pendidikan formalnyadilaksanakan pada usia 4-6 tahun. Hal ini sesuai dengan yang terdapatdalam kurikulum berbasis kompetensi yang menjelaskan bahwa anak usiadini 4-6 tahun merupakan bagian dari anak usia dini yang berada padarentang usia lahir sampai 6 tahun.

\section{B. Dasar Dan Tujuan Pendidikan Anak Usia Dini}

Setiap tindakan dan aktivitas harus berorientasi pada tujuan ataurencana yang telah ditetapkan. Dapat diketahui bahwa tujuan dapatberfungsi sebagai standar untuk mengakhiri usaha serta mengarahkanusaha yang dilalui dan merupakan titik pangkal untuk mencapai tujuan-tujuanlain. Di samping itu tujuan dapat membatasi ruang usaha agarkegiatan dapat terfokus pada apa yang dicita-citakan dan dapat memberipenilaian pada usaha-usahanya.Bila pendidikan kita pandang sebagai

\footnotetext{
${ }^{6}$ Ibid., hal. 42-43.
} 
suatu proses, maka prosestersebut akan berakhir pada tercapainya tujuan akhir pendidikan. Suatutujuan yang hendak dicapai oleh pendidikan pada hakikatnya adalah suatuperwujudan dari nilai-nilai ideal yang terbentuk dalam pribadi manusiayang diinginkan. Nilai-nilai ideal itu mempengaruhi dan mewarnai polakepribadian mannusia, sehingga menggejala dalam perilaku lahiriyahnya.Dengan kata lain perilaku lahiriyah adalah cermin yang memproyeksinilai-nilai ideal yang telah mengacu di dalam jiwa manusia sebagai produkdari proses kependidikan. ${ }^{7}$

Tujuan adalah sesuatu yang akan dituju atau akan dicapai dengansuatu kegiatan atau usaha. Dalam kaitannya dengan pendidikan makamenjadi suatu yang hendak dicapai dengan kegiatan atau usaha dalamkaitannya dengan pendidikan.

Islam sangat memperhatikan anak dengan memberikan kepadanya pendidikan Islami. Agar seorang anak mendapat petunjuk yang jelas dalam perjalanan menuju kehidupan yang mulia. Ketika mulai mempersiapkan individunya, Islam menganggap individu ini sebagai salah satu elemen yang akan membentuk sebuah keluarga dan masyarakat. Individu yang dimaksud ini, tidak lain adalah seorang anak.

Pada permulaannya seorang anak dibentuk oleh fitrah, norma-norma dan pemahaman-pemahaman yang ada pada manusia. Dan seorang anak hanya menjadi beradab oleh prinsip-prinsip kemanusiaan dan akhlak-akhlak terpuji, yang semua itu tidak mungkin didapat kecuali dari prinsip-prinsip dan nilai-nilai yang ada pada Islam. ${ }^{8}$

Dasar, fungsi dan tujuan pendidikan di Indonesia adalah sesuaidengan Undang-Undang Republik Indonesia Nomor 20 Tahun 2003tentang System Pendidikan Nasional pada Bab II pasal 2 dan 3menyebutkan bahwa:

Pasal 2: "Pendidikan Nasional berdasarkan Pancasila dan UndangUndangDasar Negara Republik Indonesia Tahun 1945".

Pasal 3: "Pendidikan Nasional berfungsi mengembangkan kemampuan danmembentuk watak serta peradaban bangsa yang bermartabatdalam

\footnotetext{
${ }^{7}$ H.M. Arifin, Filsafat Pendidikan Islam (Jakarta: Bumi Aksara, 1991), hal. 199.

${ }^{8}$ Fuhaim, Musthofa, Kurikulum Pendidikan Anak Muslim (Surabaya: Pustaka Elba,2009),
} hal 30 . 
rangka mencerdaskan kehidupan bangsa, bertujuan untukberkembangnya potensi peserta didik agar menjadi manusia yangberiman dan bertaqwa kepada Tuhan Yang Maha Esa, berakhlaqmulia, sehat, berilmu, cakap, kreatif, mandiri, dan menjadi wargaNegara yang demokratis serta bertanggung jawab". ${ }^{9}$

Menurut penjelasan pasal di atas maka dasar pelaksanaanpendidikan anak usia dini atau pendidikan prasekolah yang mengacukepada pendidikan nasional ialah berdasarkan pada pancasila dan undang-undangdasar Negara Republik Indonesia Tahun 1945. Tujuan umum darilembaga pendidikan anak usia dini yang mengacu kepada tujuanpendidikan nasional di Indonesia yaitu untuk menghasilkan manusia yangberiman dan bertaqwa kepada Tuhan Yang Maha Esa, berbudi pekertiyang luhur, berkepribadian, berdisiplin, bekerja keras, tangguh, bertanggung jawab, mendiri, cerdas dan terampil, serta sehat jasmani danrohani. Sedangkan tujuan khusus dari pendidikan anak usia dini adalah:

a. Memberi kesempatan kepada anak untuk memenuhi kebutuhankebutuhanfisik maupun psikologinya dan mengembangkan potensipotensiyang ada padanya secara optimal sebagai individu yang unik.

b. Memberi bimbingan yang seksama agar anak memiliki sifat dankebiasaan yang baik, sehingga mereka dapat diterima olehmasyarakatnya.

c. Mencapai kematangan mental dan fisik yang dibutuhkan agar dapatmelanjutkan pada jenjang pendidikan yang lebih tinggi. ${ }^{10}$

Searah dengan tujuan tersebut, lembaga pendidikan anak usia dini dimaksudkan sebagai suatu tempat bagi anak untuk mendapatkan kesempatan bimbingan yang terarah bagi perkembangan proses sosial bagi anak melalui cara yang sesuai dengan sifat-sifat alami yang dimilikinya. Oleh karena itu penyelenggaraan pendidikan di lembaga pendidika anak usia dini harus sesuai dengan tujuan yang hendak dicapai sehingga dapat terwujud dengan baik.

\footnotetext{
${ }^{9}$ Undang-Undang Republik Indonesia No. 20 Tahun 2003 tentang Sistem Pendidikan Nasional (Bandung: Citra Umbara, 2003), hal. 7.

${ }^{10}$ Soemiarti Patmonodewo, Op.Cit., hal. 59.
} 


\section{Kurikulum Dalam Pendidikan Anak Usia Dini}

Untuk dapat memberikan pendidikan yang dapatdipertanggungjawabkan, maka setiap sekolah perlu mempunyai sebuahrencana pendidikan yang sistematis, yaitu disebut kurikulum. Dalamkurikulum ini tercantum segala sesuatu yang dilakukan untuk memdidikanak dan yang berhubungan erat dengan pendidikan tersebut. Misalnya:tujuan pendidikan, mata pelajaran atau kegiatan di sekolah, bahanpelajaran dan rinciannya untuk setiap tingkatan, cara pelaksanaannya dansebagainya.Ada beberapa batasan kurikulum yang sesuai dengan kurikulumpendidikan TK. Kurikulum adalah, seluruh usaha atau kegiatan sekolahuntuk merangsang anak supaya belajar, baik di dalam maupun di luarkelas. Anak tidak terbatas belajar dari apa yang diberikan disekolah saja. Seluruh pengembangan aspek seseorang dijangkau dalam kurikulum inni, baik aspek fisik, intelektual, sosial maupun emosional. ${ }^{11}$ Pada Taman Kanak-Kanak, kurikulum itu disebut dengan istilah Program Kegiatan Belajar (PKB). ${ }^{12}$

Pemerintah telah memutuskan bahwa pendidikan TK merupakanwadah untuk membantu pertumbuhan dan perkembangan jasmani danrohani anak didik sesuai dengan sifat alami anak. Sedangkan kesempatanuntuk mengembangkan diri itu memerlukan fasilitas dan saranapendukung dalam berbagai bentuk seperti saran pendidikan yangmenunjang. Semua fasilitas dan kesempatan pengembangan diri anaktersebut tersedia di TK. ${ }^{13}$

Program kegiatan belajar TK merupakan satu kesatuan programkegiatan belajar yang utuh. Program kegiatan ini berisi bahanbahanpembelajaran yang disusun menurut pendekatan tematik. Dengandemikian bahan tersebut merupakan tema-tema yang dikembangkan lebihlanjutoleh guru menjadi program kegiatan pembelajaran yang operasional. Tema yang digunakan dalam program kegiatan belajar TK

\footnotetext{
${ }^{11}$ Soemiarti Patmonodewo, Op.Cit., hal. 56.

12 Ibrahim Bafadal, Dasar-Dasar Manajemen Dan Supervise Taman Kanak-Kanak (Jakarta: Bumi Aksara, 2005). hal. 6.

${ }^{13}$ Soemiarti Patmonodewo, Op.Cit., hal. 68
} 
kelompok A dan B, adalah: aku, panca indra, keluargaku, rumah, sekolah, makanan, kendaraan, makanan dan minuman, pakaian, kebersihan, kesehatan dan keamanan, binatang, tanaman, kendaraaan, pekerjaan, rekreasi, air dan udara, api, negaraku, alat komunikasi, gejala alam, matahari, bulan, dan bintang, kehidupan di kota, desa pesisir, dan pegunungan. Lama pendidikan di TK, satu atau dua tahun sesuai dengan usiaanak. Jika suatu TK memilih program satu tahun, TK tersebut dapatmenyelenggarakan kelompok A ataukelompok B. jika memilih programdua tahun, maka TK tersebut menyelenggarakan kelompok A dankelompok B yang lamanya masing-masing satu tahun. Pendidikan prasekolah memperhatikan beberapa prinsip pendidikan antara lain: (1) TK merupakan salah satu bentuk awal pendidikan sekolah, untuk itu perlu menciptakan situasi pendidikan yang dapat memberikan rasa aman dan menyenangkan; (2) masing-masing anak perlu mendapat perhatian yang bersifat individual, sesuai dengan kebutuhan anak usia prasekolah; (3) perkembangan adalah hasil proses kematangan dan proses belajar; (4) kegiatan belajar TK adalah pembentukan perilaku melalui pembiasaan yang terwujud dalam kegiatan sehari-hari; (5) sifat kegiatanbelajar di TK merupakan pengembangan kemampuan yang telah diperoleh di rumah; (6) bermain merupakan cara yang paling baik untuk mengembangkan kemampuan anak didik. ${ }^{14}$

\section{Metode Penanaman Keagamaan Pada Anak Usia Dini}

Masa anak-anak bukanlah masa pembebanan hukum (taklif). Masaanak-anak adalah masa latihan dan persiapan (I'dad wa tadrib), sertapembiasaan (ta'wid) untuk menuju ke masa pembebanan hukum pada saatdewasa balig. Tujuannya adalah agar anak-anak dapat melaksanakankewajiban dengan mudah, dan berada pada kondisi

${ }^{14}$ DEPDIKNAS, Kurikulum 2004 Standar Kompetensi Taman Kanak-Kanak Dan Raudlatul Athfal (Jakarta:2004), hal. 7. 
persiapan yangsempurna untuk mengarungi kehidupan dengan segala kekuatan. $^{15}$

Tujuan pendidikan dalam Islam tergambar dalam keikhlasanberibadah kepada Allah Ta'ala, dan penanaman akidah yang murni di dalamjiwa anak. Media yang paling penting dalam mengajarkan akidah yangbenar kepada anak adalah menyampaikan keyakinan tauhid sepertiberiman kepada Allah dan Malaikat-Nya, beriman kepada takdir, danpentingnya mencintai Allah dan Rasul-Nya, dengan format yangsederhana, yang bisa dicerna oleh anak.

Metode penanaman akidah yang bersih sejak kecil merupakanpersoalan yang sangat penting dalam manhaj tarbiyah Islam. Allah Ta'ala telahmenganugerahkan dua kelebihan kepada manusia sebagai sumberkebahagiaan. Pertama, bahwa setiap anak dilahirkan dalam keadaan suci.Kedua, bahwa Allah Ta'ala memberikan hidayah kepada semua manusiadengan apa yang Dia ciptakan pada mereka dengan fitrah.Termasuk kewajiban pendidik yang paling penting adalahmemelihara fitrah anak dari penyimpangan dan membentengi akidah darisyirik. Wajib memberitahukan kepada anak bahwa ia adalah orangmuslim, bahwa agamanya adalah agama yang diridhai Allah Ta'ala, bahwa Allah Ta'alatidak akan menerima dari hamba-Nya selain Islam.Terkadangorang tua kebingungan untuk menjelaskan seputar akidahdi depan anak. Kewajiban orang tua dan pendidik terhadap anak adalahmengajarkan keimanan secara murni dengan metode yang palingmendekati dan paling mudah untuk dipahami. Seperti cara Rasulullah-alaihissolatuwassalm-. Berinteraksi dengan anak-anak, adalah sebagai berikut:

a. Mengajarkan kata Allah kepada anak pada awal pembicaraannya,kemudian melanjutkan dengan kalimat tauhid.

b. Menanamkan kecintaan kepada Allah dan kecintaan kepada Rasulullah pada awal kesadaran, pengetahuan, dan kemampuanmembedakan baik-buruk.

${ }^{15}$ Khalid Bin Abdurrahman Al-'Akk, Cara Islam Mendidik Anak (Yogyakarta: AdDawa', 2006), hal. 144. 
c. Mengajarkan Al-Qur'an kepada anak, dimulai dari surat-surat pendek,kemudian surat panjangdan seterusnya, disertai dengan membiasakanmembaca dan mendengarkan bacaannya.

d. Membiasakan anak shalat. ${ }^{16}$

Tidak hanya di rumah saja di sekolah pun seorang pendidik juga harusmenanamkan jiwa keagamaan pada diri anak. Pendidik sebagai suritauladan dalam kegiatan belajar mengajar harus berkomunikasi dua arahdengan anak-anak berdasar keihklasannya.Pendidikan agama di prasekolah Islam mencakup gagasan-gagasanuntuk perkembangan total pribadi anak. Pribadi Islami ini akan munculhanya jika nilai-nilai danpengetahuan Islam digabungkan dengan programpelatihan dan pendidikan anak secara total. Setiap aspek dalam kehidupanpribadi harus dibimbing oleh prinsip-prinsip abadi dalam Islam.

Kurikulum pelajaran Islam di prasekolah dilengkapi denganpembelajaran yang lebih terfokus pada cara kehidupan dan perilaku Islami,dari pada pengajaran dan pembelajaran mengenai Islam sebagai salah satubidang pelajaran. Guru harus menciptakan lingkungan Islami di dalamsekolah dan ruang kelas, dan harus menjadi model percontohan seorangmuslim yang baik. Mereka harus membiasakan adanya perilaku Islami,menggunakan ucapan-ucapan yang baik, memakai baju-baju muslim,sebagai salah satu pembentukan perkembangan alami di dalam kelas.Pendidik harus menggunakan cerita-cerita dan ilustrasi-ilustrasi darisunnah Rasul sesering mungkin, agar bisa dijadikan contoh untuk anaanak. Seorang pendidik haruslah menumbuhkan kesadaran bahwa Allah Ta'ala adalah pencipta semesta alam terhadap anak, diantaranya adalah dengan cara memperkenalkan ciptaan Allah yang ada disekitarnya, seperti: Allah telah menciptakan bermacam-macam tanaman, menciptakan bermacam-macam hewan dan Allah juga menciptakan semuanya dalam bentuk berpasang-pasangan. ${ }^{17}$ Selain itu pendidik juga harus menanamkan

\footnotetext{
${ }^{16}$ Ibid., hal. 129-136.

17 Wahyudi, Dwi Retna Damayanti, Program Pendidikan Untuk Anak Usia Dini Di Prasekolah Islam (Jakarta: Grasindo, 2005), hal. 28.
} 
rasa cinta kepada Rasulullah SAW pada jiwa anak, sebab cinta kepada Rasulullah SAW termasuk bagian dari cinta kepada Allah. Seseorang tidakakan menjadi mukmin kecuali dengan mencintai Allah dan RasulNya. $^{18}$

Ada beberapa metode untuk menumbuhkan rasa keagamaan pada anakusia dini, diantaranya adalah:

a. Pembiasaan

Hendaknya setiap pendidik menyadari bahwa dalam pembinaan pribadi anak sangat diperlukan pembiasaan-pembiasaan dan latihanlatihan yang cocok dan sesuai dengan perkembangan jiwanya. Karena pembiasaan dan latihan tersebut akan mambentuk sikap tertentu pada anak, yang lambat laun sikap itu akan bertambah jelas dan kuat, akhirnya tidak tergoyahkan lagi, karena telah masuk menjadi bagian dari pribadinya.

Pertumbuhan kecerdasan pada anak belum memungkinkan untukberfikir logis dan belum dapat memahami hal-hal yang abstrak, makaapapun yang dikatakan kepadanya akan diterimanya saja. Dia belumdapat menjelaskan mengapa ia harus percaya kepada tuhan dan belumsanggup menentukan mana yang baik dan mana yang buruk. Hukum-hukumdan ketentuan agama belum dapat dipahaminya ataudipikirkannya sendiri, dia akan menerima saja apa yang dijelaskankepadanya tanpa memerlukan penjelasan lagi.Pembentukan sikap, pembinaan moral, dan pribadi pada umunya,terjadi malalui pengalaman sejak kecil. Pendidik atau pembina pertamaadalah orang tua, kemudian guru, semua pengalaman yang dilalui olehanak waktu kecilnya, akan merupakan unsur penting dalam pribadinya. Sikap si anak terhadap agama dibentuk pertama kali di rumah malalui pengalaman yang didapatnya dengan orang tuanya, kemudian disempurnakan atau diperbaiki oleh guru di sekolah. Kalau guru agamadapatmembuat dirinya disayangi oleh murid-murid maka pembinaansikap positif terhadap agama akan mudah terjadi. Latihan-latihan keagamaan yang menyangkut ibadah seperti sholat, doa, membaca Al-Qur'an di sekolah, di masjid, harus dibiasakan

\footnotetext{
${ }^{18}$ Khalid Bin Abdurrahman Al-‘Akk, Op.Cit., hal. 132.
} 
sejak kecil, sehingga lama kelamaan akan tumbuh rasa senang melakukan ibadah tersebut. ${ }^{19}$

Dari pernyataan di atas dapat disimpulkan bahwa, pembiasaandalam pendidikan anak sangat penting, terutama dalam pembentukanpribadi, akhlak dan agama pada umumnya. Karena pembiasaanpembiasaanagama akan memasukkan unsur-unsur positif dalampribadi anak yangsedang tumbuh. Semakin banyak pengalaman agamayang didapatnya melalui pembiasaan itu, akan semakin banyaklahunsur agama dalam pribadinya dan semakin mudahlah ia memahamiajaran agama yang akan dijelaskan oleh guru agama di belakang hari.

b. Keteladanan

Yang dimaksud dengan keteladanan disini adalah seseorang yangmemberikan suatu contoh yang baik, akhlak yang tangguh, memahamijiwa agama yang benar, disamping itu kemampuannya mengikutiperkembangan zaman.Pada masa Rasulullah dakwah Islam yang hampir tujuh puluhlima persen (75\%) dengan menggunakan metode contoh atau tingkahlaku atau perbuatan yang baik. Sedang Rasul itu sendiri adalahmerupakan contoh teladan utama yangmenjadi kiblat dari segalaperbuatan pengikutnya. Seperti firman Allah Ta'ala dalam Al-Qur'an surat al-Ahzab ayat 21Artinya: "Sesungguhnya Telah ada pada (diri) Rasulullah itu suri teladan yang baik bagimu (yaitu) bagi orang yang mengharap (rahmat) Allah dan (kedatangan) hari kiamat dan dia banyak menyebut Allah". ${ }^{20}$

Teladan merupakan salah satu pedoman bertindak. Anak didikcenderung meneladani pendidiknya, ini diakui oleh semua ahlipendidikan. Dasarnya adalah karena secara psikologis anak memangsenang meniru, tidak saja yang baik, yang jelek pun ditirunya.Pusat daripendidikan Islam adalah metode keteladanan. Gurumenjadi teladan bagi muridnya, pemimpin menjadi teladan bagimasyarakatnya. Sedangkan teladan bagi semua umat

\footnotetext{
${ }^{19}$ Zakiah Darajat, Ilmu Jiwa Agama (Jakarta: Bulan Bintang, 1976), hal. 77-81.

${ }^{20}$ Al-Qur'an dan Terjemahannya, Op.Cit., hal. 670.
} 
adalahRasulullah.Rasul meneladankan bagaimana kehidupan yangdikehendaki Allah karena Rasul itu adalah penafsiran ajaran Allah. ${ }^{21}$

Secara psikologis manusia memang memerlukan tokoh teladandalam hidupnya, ini adalah sifat pembawaan. Meniru adalah salah satusifat pembawaan manusia. Oleh karena itu dalam pendidkan agamapada anak perlu adanya tokoh yang dijadikan teladan yang baiksehingga anak akan meniru sesuatu yang baik.

c. Metode Cerita

Cerita merupakan salah satu jenis sastra yang memiliki nilaiestetika. Di dalamnya terdapat rasa kenikmatan yang tiada tara sertamempu menyedot perhatian anak-anak dan orang dewasa. Targettersebut baru bisa dicapai jika skenario ditulis dengan baik,disampaiakan dengan memukau dan dapat didengarkan audien yangberjiwa seni. Cerita adalah sastra yang yang berbentuk tulisan (yangdikonsumsi melalui bacaan) atau berbentuk lisan (yang dikonsumsimelalui audiensi). ${ }^{22}$

Metode bercerita merupakan salah satu pemberian pengalamanbelajar bagi anak dengan membawakan cerita kepada anak secaralisan. Bila isi cerita itu dikaitkan dengan dunia kehidupan anak usiadini, maka mereka dapat memahami isi cerita itu, mereka akanmendengarkan dengan penuh perhatian, dan dengan mudah dapatmenangkap isi cerita. Kegiatan bercerita akan memberikan sejumlahpengetahuan sosial, nilai-nilai moral, dan keagamaan. Kegiatanbercerita juga memberikan pengalaman belajar untuk berlatihmendengarkan. Melalui mendengarkan anak memperoleh bermacaminformasi tentang pengetahuan, nilai, dan sikap untuk dihayati danditerapkan dalam kehidupan sehari-hari.Memberi pengalaman belajar dengan menggunakan metodebercerita memungkinkan anak mengembangkan kemampuan kognitif,afektif, maupun psikomotorik masing-masing anak. Bila anak terlatihmendengarkan dengan baik, maka ia akan terlatih untuk menjadipendengar yang kreatif dan kritis. Pendengar yang kreatif mampumelakukan pemikiran-pemikiran baru berdasarkan apa

\footnotetext{
${ }^{21}$ Ahmad Tafsir, Op.Cit., hal. 142-143.

${ }^{22}$ Abdul Aziz Abdul Majid, Mendidik Anak Lewat Cerita Dilengkapi 30 Kisah (Jakarta: Mustaqiim, 2003), hal. 19-20.
} 
yangdidengarkannya. Pendengar yang kritis mampu menemukanketidaksesuaian antara apa yang didengar dengan apa yang dipahami. $^{23}$

Pendidikan dalam Islam, metode cerita sangatlah penting, karenamempunyai alasan sebagai berikut:

1) Cerita selalu memikat karena mengundang pembaca ataupendengar untuk mengikuti peristiwanya, merenungkan maknanya.

2) Cerita yang bersifat qurani dan nabawi dapat menyentuh hatimanusia karena kisah itu menampilakn tokoh dalam konteksmenyeluruh.

3) Cerita yang bersifat qurani mendidik perasaan keimanan dengancara:

a) Membangkitkan berbagai perasaan seperti khauf, ridha dancinta.

b) Mengarahkan seluruh perasaan sehingga bertumpuk pada suatupuncak, yaitu kesimpulankisah.

c) Melibatkan pembaca atau pendengar ke dalam kisah itusehingga ia terlibat secara emosional. Cerita yang bersifat qurani dan nabawi bukanlah semata ceritaatau semata-mata karya seni yang indah, tetapi suatu cara untukmendidik anak agar beriman kepada Allah dan Rasul-Nya.Dengan demikian, metode cerita sangatlah penting dalammenumbuhkan dan menanamkan rasa keagamaan kepada anak. $^{24}$

d. Metode Demonstrasi

Metode demonstrasi adalah metode mengajarkan yangmenggunakan peragaan untuk memperjelas suatu pengertian atauuntuk memperlihatkan bagaimana melakukan sesuatu kepada anakdidik. Memperjelas pengertian tersebut dalam prakteknya dapatdilakukanoleh guru itu sendiri atau langsung oleh anak didik.Dengan metode demontrasi guru atau murid memperlihatkanpada seluruh anggota kelas sesuatu proses, misalnya bagaimana carashalat yang sesuai dengan ajaran Rasulullah SAW.Beberapa keuntungan atau kebaikan dalam metode demontrasi,yaitu:

${ }^{23}$ Moeslichatoen R., Metode Pengajaran Di Taman Kanak-Kanak (Jakarta: PT.Rineka Cipta, 1999), hal. 157-168.

${ }^{24}$ Ahmad Tafsir, Op.Cit., hal. 140-141. 
1) Perhatian anak didik dapat dipusatkan, dan titik berat yangdianggap penting oleh guru dapat diamati secara tajam.

2) Perhatian anak didik akan lebih terpusat kepada apa yangdidemontrasikan, jadi proses belajar anak didik akan lebih terarahdan akan mengurangi perhatian anak didik kepada masalah lain.

3) Apabila anak didik sendiri ikut dalam sesuatu percobaan yang bersifat demontratif, maka mereka akan memperoleh pengalamanyang melekat pada jiwanya dan ini berguna dalam pengembangankecakapan. Dalam menamankan jiwa keagamaan pada anak, banyak yang dapat didemontrasikan, terutama dalam bidang pelaksanaan shalat, zakat beberapa pelaksanaan rukun haji dan lain sebagainya. Pada saat anak didik mendemontrasikan shalat, guru harus mengamati langkah demi langkah dari setiap gerak gerik murid tersebut, sehingga kalau ada segi-segi yang kurang, guru berkewajiban memperbaikinya. Tindakan mengamati segi-segi yang kurang baik lalu memperbaikinya akan mamberi kesan yang dalam pada diri anak didik, karena guru berarti telah memberi pengalaman kepada anak didik, baik bagi anak didik yang menjalankan demontrasi ataupun bagi yang menyaksikan. Dengan tambahan pengalaman ini akan menjadi dasarpengembangan kecakapan dan keterampilan dari anak didik yang kitaasuh, terutamaapabila dilaksanakan dalam pengajaran agama. ${ }^{25}$

e. Metode Karyawisata

Metode karyawisata ialah suatu metode pengajaran yang dilaksanakan dengan jalan mengajak anak-anak keluar kelas untuk dapat memperlihatkan hal-hal atau peristiwa yang ada hubungannya dengan bahan pelajaran. Dalam perjalanan karyawisata ada hal-hal tertentu yang telah direncanakan oleh guru untuk didemonstrasikan atau ditunjukkan kepada anak didik, di samping ada hal-hal yang secara kebetulan

\footnotetext{
${ }^{25}$ Metodik Khusus Pengajaran Agama Islam (Jakarta: Direktorat Pembinaan Perguruan Tinggi Agama Islam, 1981), hal. 236-237.
} 
diketemukan dalam perjalanan berkaryawisata tersebut. Misalnya: pengenalan terhadap kekuasaan Tuhan dalam penciptaan alam semesta. ${ }^{26}$

Karyawisata merupakan salah satu metode melaksanakan kegiatan pengajaran di lembaga pendidikan anak usia dini dengan cara mengamati dunia sesuai dengan kenyataan yang ada secara langsung yang meliputi manusia, hewan, tumbuh-tumbuhan, dan benda-benda lainnya. Dengan mengamati secara langsung anak memperoleh kesanyang sesuai dengan pengamatannya. $^{27}$

Dalam penerapan metode karyawisata sangat tepat dilakukanapabila:

1) Pelajaran dimaksudkan untuk memberi pengertian lebih jelasdengan alat peraga langsung.

2) Membangkitkan penghargaan dan cinta terhadap lingkungan dantanah air, serta menghargai ciptaan Allah Ta'ala.

3) Mendorong anak mengenal masalah lingkungan dengan baik.

Dengan melalui metode karyawisata akan memberi kepuasanterhadap keinginan anak didik dengan banyak melihat kenyataankenyataandi samping keindahan alam sekitar di luar kelas. Selain ituanak didik juga akan bersikap terbuka, obyektif, luas pandangan akibatdari pengetahuan luar yang diperolehnya yang akan mempertinggiprestasi kepribadiannya dan juga anak didik memperoleh tambahanpengalaman melalui karyawisata, sedangkan guru mendapatkesempatan menerangkan segala sesuatu. Dalam penerapan metode karyawisata, guru hendaknya merumuskan terlebih dahulu tujuan pelajaran dengan jelas, sehingga kelihatan wajar tidaknya metode ini digunakan, dan juga hendaknya guru menyelidiki terlebih dahulu obyek yang akan ditinjau dengan memperhatikan hal-hal yang sekiranya akan menjadi kesulitan. Selainitu perlu juga dijelaskan terlebih dahulu tujuan karyawisata dandisiapkan pertanyaan-pertanyaan yang harus mereka jawab. ${ }^{28}$

${ }^{26}$ Zuhairini, Abdul Ghafir, dan Slamet As. Yusuf, Metodik Khusus Pendidikan Agama (Surabaya: Usaha Nasional, 1981), hal. 104.

${ }^{27}$ Moeslichatoen R., Op.Cit., hal. 68.

${ }^{28}$ Zuhairini, Abdul Ghafir, dan Slamet As. Yusuf, Op.Cit., hal. 104-105. 
Penerapan metode karyawisata sangat baik digunakan untuk menanamkan jiwa keagamaan pada anak, karena dengan karyawisata anak didik akan mengetahui dan melihat secara langsung banyaknya dan indahnya ciptaan Allah Ta'ala.

\section{E. Faktor Pendukung Dalam penerapan Metode PenanamanKeagamaan}

\section{Pada Anak Usia Dini}

a. Sarana dan fasilitas kelas

Lingkungan fisik tempat belajar mempunyai pengaruh pentingterhadap hasil perbuatan belajar. Lingkungan fisik yangmenguntungkan dan memenuhi syarat minimal mendukungmeningkatnya intensitas proses perbuatan belajar murid danmempunyai pangaruh positif terhadap pencapaian tujuan pengajaran. Hal ini juga dikatakan oleh Dhoroty yang dikutib oleh Bobbi Deporter dkk dalam bukunya "Quantum Teaching" bahwa "segala sesuatu dalam lingkungan kelas menyampaikan pesan memacu atau menghambat belajar."29

Dari cara poster ditempelkan di dinding, pengaturan bangku,penyusunan bahan persediaan, hingga kebersihan kelas semuanyaberbicara. Diantaranya adalah:
a. Ruangan tempat berlangsungnya proses belajar mengajar
b. Pengaturan tempat duduk
c. Ventilasi dan pengaturan cahaya

b. Faktor guru

Sikap dan sifat guru akan mempunyai pengaruh yang cukup besarterhadap proses belajar mengajar, kegairahan murid efektifitastercapainya tujuan pengajaran. Diantaranya adalah:

4) Tipe kepemimpinan guru

Seorang guru harus bersifat demokratis, dengan sikapdemokratis lebih memungkinkan terbinanya sikap persahabatanguru dengan murid. Sikap ini dapat membantu menciptakan iklimyang menguntungkan bagi terciptanya kondisi proses belajarmengajar yang optimal.

\footnotetext{
${ }^{29}$ Bobbi Deporter, Quantum Teaching. (Bandung: Mizan Media Utama, 2000), hal. 66.
} 
5) Sikap guru

Sikap guru dalam menghadapi murid yang melanggar peraturan sekolah hendaknya tetap sabar, dan tetap bersahabat dengan suatu keyakinan bahwa tingkah laku murid akan dapat diperbaiki.

6) Suara guru

Suara guru walaupun bukan faktor yang besar tetapi turutmempengaruhi dalam belajar. Suara yang melengking tinggi ataurendah sehingga tidak terdengar oleh murid secara jelas dari jarakyang agak jauh akan membosankan dan pelajaran tidak akandiperhatikan

c. Faktor lingkungan

Faktor lingkungan bisa menentukan keberhasilan pendidikanataupun pengajaran, jika lingkungan itu bisa mendukung kegiatantersebut. Sebagaimana yang dikatakan Amir Daien Indra kusuma:Pengaruh yang positif yaitu apabila lingkungan itu memberikankesempatan yang baik serta memberikan dorongan atau motivasiterhadap pembentukan dan perkembangan anak. ${ }^{30}$

Begitu juga dengan taman kanak-kanak yang merupakan tempatbagi anak usia dini sebagai pemula dalam memasuki bangku sekolah,situasinya diusahakan menjadi baik, yang pada akhirnya biasmendukung dan memperlancar jalannya penerapan Pendidikan AgamaIslam dengan baik.

\section{F. Faktor Penghambat Dalam Penerapan Metode penanamanKeagamaan Pada Anak Usia Dini}

a. Faktor siswa

Peserta didik dalam kelas dapat dianggap sebagai seorangindividu dalam suatu masyarakat kecil yaitu kelas dan sekolah. Merekaharus tahu hak-hak yang sebagai bagian dari satu kesatuan masyarakatdisamping mereka juga harus tahu akan kewajibannya dan keharusanmenghormatihak-hak orang lain dan teman-teman sekelasnya. Kekurangsadaran peserta didik dalam memenuhi tugas dan haknya

${ }^{30}$ Amir Daien Indrakusuma. Pengantar Ilmu Pendidikan (Surabaya: Usaha Nasional, 1973), hal. 32 
sebagai anggota suatu kelas atau suatu sekolah dapat merupakan faktor utama penyebab hambatan pengelolaan kelas.

Masalah yang bersumber dari siswa dapat dikelompokkanmenjadi dua, yaitu masalah individu dan masalah kelompok. Dapatterjadi masalah individual berkembang menjadi masalah kelompok,atau sebaliknya. Seorang siswa yang melawak di kelas gaduh misalnya(masalah individu), bagi seorang guru yang baru masuk, masalahtersebut akan nampak sebagai masalah kelompok. Atau sebaliknya ,sekelompok siswa yang tidak senang terhadap guru lalu mendorongseorang temannya untuk selalu menganggu jalannya kegiatan belajarmengajar (masalah kelompok), sepintas lalu akan nampak sebagaimasalah individual. ${ }^{31}$

b. Faktor Keluarga

Tingkah laku dikelas merupakan pencerminan keadaankeluarganya. Sikap otoriter orang tua akan tercermin dari tingkah lakumurid yang agresif atau apatis. Di dalam kelas sering ditemukan adamurid penganggu dan pembuat ribut. Mereka itu biasanya berasal darikeluarga yang tidak utuh dan kacau (broken-home). Kebiasaan yang kurang baik di lingkungan keluarga seperti tidak tertib, tidak patuh pada disiplin, kebebasan yang berlebihan ataupun terlampau dikekang akan merupakan latar belakang yang menyebabkan murid melanggar disiplin dikelas. Jelaslah sudah bahwa bila tuntutan di kelas atau sekolah berbeda jauh dengan kondisi kehidupan keluarga akan merupakan kesukaran tersendiri bagi murid untuk menyesuaikan diri. Di sinilah letak pentingnya hubungan kerja sama yang seimbang antara sekolah dengan keluarga agar terdapat keselarasan antara situasi dan tuntutan dalam lingkungan keluarga dengan situasi dan tuntutan di kelas atau sekolah.

${ }^{31}$ A.J.E Teonlioe, Teori Dan Praktek Pengelolaan Kelas, (Surabaya: Usaha Nasional, 1992), hal. 19. 


\section{Penutup}

Pertumbuhan anak di usia dini amat penting dan menentukan. Apa yang terbentukdi usia itu akan mempengaruhi tingkat kecerdasan dari watak atau kepribadian anak selanjutnya.. Dalam penanaman keagamaan menggunakan pendekatan tematik yaitu disini, guru ditantang untuk lebih kreatif bagaimana mengenalkan agama Islam kepada murid, dengan cara tema yang akan dibahas, guru harus menghubungkan dengan agama. Apabila guru membahas tema tentang olah raga atau kesehatan maka guru harus mengkaitkan dengan agama.

Selain itu, dari pihak sekolah membuat program pendidikan khususdidalam kurikulum yang ada, guru membuat program jam khusus pengajaran dibuat untuk praktek tata cara Wudhu dan Shalat. Dalam pengenalan keagamaan pada murid, metode yang digunakan meliputi: Pembiasaan, Keteladanan, Metode Cerita, Demonstrasidan Karyawisata

Faktor penghambat dan faktor pendukung tidak terlepas dari lingkungan sekolah ataupun keluarga, maupun dari murid itu sendiri. Yang menjadi penghambat dan pendukung jalannya pengajaran dominan pada faktor keluarga dan murid itu sendiri. Menjadi penghambat karena, apabila ada murid yang tingkat kecerdasannya rendah maka guru harus ekstra keras dalam mendidik dan akan menghambat jalannya pengajaran yang sudah terancana sedangkan keluarga tidak mendukung karena faktor ekonomi maupun karena rendahnya pengetahuan mereka terutama pada ilmu agama. Dan begitu juga sebaliknya, keluarga dan murid menjadi pendukung dalam proses belajar mengajar karena, dengan adanya piket yang dikhususkan wali murid sangat membantu guru dalam perkembangan dan kemajuan sekolah serta mendukung proses pembelajaran. 


\section{Pustaka Acuan}

Abdussalam,Suroso. ArahdanAsasPendidikanIslam.Bekasi: SuksesPublishing, 2011. , SistemPendidikan Islam.Bekasi: Sukses Publishing, 2011.

, Cara Mendidik Anak Sejak lahir Hingga TK. Surabaya: Sukses Publishing, 2001.

Ahmad, Farid. Pendidikan Berbasis Metode Ahlu Sunnah Wal Jama'ah. Surabaya: Pustaka Elba, 2011.

Dalyono, M. PsikologiPendidikan.Jakarta: RinekaCipta, 2005.

Djamarah, Syaiful Bahri dan Aswan Zain. Strategi Belajar Mengajar. Jakarta: Rineka Cipta, 2002.

Djamarah, SyaifulBahri. Guru Dan Anak Didik Dalam Interaksi Edukatif. Jakarta: Rineka Cipta, 2000.

Fuhaim, Musthofa. Kurikulum Pendidikan Anak Muslim, Surabaya: Pustaka Elba, 2009.

Mansur. Pendidikan Anak Usia Dini Dalam Islam, Yogyakarta: Pustaka Pelajar, 2005.

Musthofa, Yasin, EQ Untuk Anak Usia Dini Dalam Pendidikan Islam, Yogyakarta: Sketsa, 2007.

Nata, Abudin. Filsafat Pendidikan Islam, Jakarta: PT.Logos, 2001.

Rasyid,Daud. MelawanSekuralisme.Jakarta: Usamah Press, 2009.

Tafsir, Ahmad, Filsafat Pendidikan Islam. Bandung: PT. Remaja Rosdakarya, 2008. 